\title{
Application of Insecticides on Eggs of Callosobruchus chinensis L. Using Different Types of Pulse Seeds
}

\author{
M. Z. A. Pramanik AND M. A. Sardar ${ }^{*}$ \\ Department of Entomology, Bangladesh Agricultural University, Mymensingh, Bangladesh
}

Received 07 February 2005; received in revised form 10 April 2005; accepted 22 June 2006

\begin{abstract}
Experiments were carried out in the laboratory to assess the effectiveness of Nogos, Malathion, Sevin and Limper on lentil, gram, grasspea, greengram and blackgram seeds with eggs of pulse beetle, Callosobruchus chinensis $L$. Insecticides were sprayed on the seeds along with eggs and found that all the tested insecticides inhibited hatching of eggs resulting in significantly lowest rate of adult emergence. Nogos and Malathion recorded the lower number of emergent adults. The overall 26.35$100 \%$ reduction of seed damage and $40-100 \%$ weight losses were achieved in insecticides treated seeds of five different types of pulses showing highest reduction in seed damage and weight losses due to Nogos and Malathion treatments. The treatment of the pulse seeds with the insecticides did not affect the seed germination.
\end{abstract}

Key words: Insecticides, pulse beetle, egg treatment, pulses, seed damage.

\section{INTRODUCTION}

Pulses being rich sources of protein play a significant role in the diet of common people of Bangladesh. But pulses are more difficult to store than cereals as they suffer a great damage during the storage due to insect pests and micro-organisms (Anon., 1978; Akhtari et al., 1993). Pulse beetle, Callosobruchus chinensis L. is considered to be a serious pest in Bangladesh causing enormous damages to almost all kinds of stored pulses. The infestation caused by this insect affects the nutritive value of the seeds and also the germination ability of the seeds (Sharma, 1984). Three-four generations of this beetle are enough to cause complete damage of pulse seeds.

Many investigators suggested to use chemicals insecticides to protect pulse and cereal crops against the attack of stored pests. A very few insecticides mainly carbamate group are used by the farmers. It is also necessary to test the efficacy of insecticides belonging to organophosphorus and pyrethroid groups against stored pests. The present work was, therefore, undertaken to study the effectiveness of some insecticides belonging to carbamate, organophosphorus and pyrethroid groups applied on the eggs laid by $C$. chinensis on lentil, gram, grasspea, greengram and blackgram seeds.

\footnotetext{
* Corresponding author: Professor, Department of Entomology, BAU. Fax: 880-91-55810

(C) 2006, School of Agriculture and Rural Development, Bangladesh Open University. All rights reserved.
} 


\section{MATERIALS AND METHODS}

Four insecticides such as Nogos 100EC and Malathion 57EC from organophosphorus, Sevin 85SP from organocarbamate, and Limper 10EC from pyrethroid group were tested at doses 0.125 , 0.0625 and $0.0312 \% \mathrm{Al}$ against the eggs of pulse beetle, $C$. chinensis on lentil, gram grasspea, greengram and blackgram seeds in the laboratory from July to October, 2000. Fifty gram seeds (moisture content $12.5-13.0 \%$ ) of lentil, gram, grasspea, greengram and blackgram seeds were taken in the plastic container $(10 \mathrm{~cm} \times 8 \mathrm{~cm}$ dia.). Seven pairs of adults of $C$. chinensis $(2-3$ days old) were released in each container and confined them inside the container closing its mouth for laying eggs on the seeds. The beetles were removed after 2 days of oviposition. The insecticides at three doses were sprayed on the seeds and each dose replicated thrice. Control treatment was included in each case. Observations were made on the number of emerged dead and alive beetles, extent of seed damage, seed weight losses and seed germination against each treatment. One hundred seeds from each replicate were taken randomly to observe egg bearing seeds and damaged seeds. To determine the germination ability of seeds, 25 undamaged seeds from each replicate was used, in petri dish with water soaked blotting paper. The room temperature and relative humidity were recorded during the period of the experiments. The data of the experiment were analysed by CRD and means were ranked by DMRT under MSTAT programme.

\section{RESULTS}

\section{Toxic Action of Insecticides}

Four insecticides such as Nogos, Malathion, Limper and Sevin were sprayed on the eggs of $C$. chinensis to see their toxic effect in five different types of pulse seeds and were assessed by observing the number of adult beetles emerged. The results of toxic action of insecticides are presented in Table 1. The emergence of the beetles differed significantly among treatments $(P<0.01)$ in all these types of pulses. The mean number of adult beetles emerged from lentil, gram, grasspea, greengram and blackgram seeds in different treatments ranged from 6.66-168.33, 6.60141.0, 4.0-133.30, 2.33-22.0 and 1.3-10.7 respectively. The untreated seeds recorded the highest number of emergent beetles. The lowest emergence of the beetles occurred on all pulse seeds treated with all doses of Nogos and Malathion followed by Sevin and Limper.

Table 1. Toxic effects of different insecticides on the emergence of $C$. chinensis on different types of pulses

\begin{tabular}{llccccc}
\hline \multirow{2}{*}{ Insecticides } & Dose & \multicolumn{5}{c}{ Mean emergent adult (no.) } \\
\cline { 2 - 7 } & (\% Al) & Gram & Lentil & Grasspea & Greengram & Blackgram \\
\hline \hline \multirow{2}{*}{ Nogos } & 0.125 & $6.6 \mathrm{~d}$ & $6.66 \mathrm{e}$ & $4.0 \mathrm{~g}$ & $2.33 \mathrm{~b}$ & $1.3 \mathrm{c}$ \\
& 0.0625 & $7.3 \mathrm{~d}$ & $11.69 \mathrm{e}$ & $9.33 \mathrm{fg}$ & $4.33 \mathrm{~b}$ & $2.0 \mathrm{c}$ \\
& 0.0312 & $10.0 \mathrm{~d}$ & $18.33 \mathrm{e}$ & $13.0 \mathrm{fg}$ & $5.66 \mathrm{~b}$ & $4.33 \mathrm{bc}$ \\
\hline \multirow{4}{*}{ Malathion } & 0.125 & $8.0 \mathrm{~d}$ & $11.33 \mathrm{e}$ & $18.0 \mathrm{efg}$ & $4.33 \mathrm{~b}$ & $1.66 \mathrm{c}$ \\
& 0.0625 & $7.0 \mathrm{~d}$ & $20.33 \mathrm{de}$ & $21.0 \mathrm{defg}$ & $3.0 \mathrm{~b}$ & $2.33 \mathrm{c}$ \\
& 0.0312 & $13.7 \mathrm{~cd}$ & $32.67 \mathrm{cde}$ & $28.0 \mathrm{cdef}$ & $6.0 \mathrm{~b}$ & $3.0 \mathrm{c}$ \\
\hline \multirow{4}{*}{ Limper } & 0.125 & $47.4 \mathrm{bc}$ & $39.33 \mathrm{cde}$ & $35.67 \mathrm{bcde}$ & $3.0 \mathrm{~b}$ & $2.66 \mathrm{c}$ \\
& 0.0625 & $69.0 \mathrm{~b}$ & $58.33 \mathrm{bcd}$ & $42.67 \mathrm{bc}$ & $4.33 \mathrm{~b}$ & $2.0 \mathrm{c}$ \\
& 0.0312 & $77.0 \mathrm{~b}$ & $81.0 \mathrm{~b}$ & $48.33 \mathrm{bc}$ & $12.33 \mathrm{~b}$ & $4.33 \mathrm{bc}$ \\
\hline \multirow{3}{*}{ Sevin } & 0.125 & $24.3 \mathrm{~cd}$ & $46.33 \mathrm{bcde}$ & $38.67 \mathrm{bcd}$ & $6.33 \mathrm{~b}$ & $2.0 \mathrm{c}$ \\
& 0.0625 & $32.7 \mathrm{~cd}$ & $60.33 \mathrm{bc}$ & $42.67 \mathrm{bc}$ & $7.33 \mathrm{~b}$ & $3.33 \mathrm{c}$ \\
& 0.0312 & $73.3 \mathrm{~b}$ & $71.67 \mathrm{bc}$ & $52.67 \mathrm{~b}$ & $13.33 \mathrm{ab}$ & $8.0 \mathrm{ab}$ \\
\hline Control & 0 & $141.0 \mathrm{a}$ & $168.3 \mathrm{a}$ & $133.3 \mathrm{a}$ & $22.0 \mathrm{a}$ & $10.7 \mathrm{a}$ \\
\hline
\end{tabular}

Means having same letter(s) did not differ significantly. 


\section{Efficacy of Insecticides as Seed Protectant}

There were $0.33-17.67 \%$ damaged seeds in treated pulses and $5.66-37.33 \%$ in control and these differed significantly $(P<0.01)$ (Table 2$)$. Among the insecticidal treatments all doses of Limper showed the higher damage in gram, lentil and grasspea than in Sevin treatments. Nogos and Malathion at all three doses significantly reduced the seed damage of these pulses ranging from $0.33-2.66 \%$. The seed damage by $C$. chinensis was generally less in blackgram and greengram than in other pulses and did not differ significantly among the insecticidal treatments. The weight losses of the seeds due to damage by $C$. chinensis were significantly higher in control than in treated seeds and $4.00-15.00 \%$ losses were found in five different types of pulses (Table 2). Gram, lentil and grasspea recorded 0.13$2.13 \%$ weight losses in insecticidal treatments. Greengram seeds had the lowest weight losses and blackgram seeds did not loose any weight in insecticide treatments.

Table 2. Seed damage and weight losses of different types of pulses treated with insecticides on eggs of C. chinensis

\begin{tabular}{|c|c|c|c|c|c|c|c|c|c|c|c|}
\hline \multirow[b]{2}{*}{ Insecticides } & \multirow[b]{2}{*}{$\begin{array}{l}\text { Dose } \\
(\% \mathrm{Al})\end{array}$} & \multicolumn{2}{|c|}{ Gram } & \multicolumn{2}{|c|}{ Lentil } & \multicolumn{2}{|c|}{ Grasspea } & \multicolumn{2}{|c|}{ Greengram } & \multicolumn{2}{|c|}{ Blackgram } \\
\hline & & $\begin{array}{c}\text { Damaged } \\
\text { seeds } \\
(\%)\end{array}$ & $\begin{array}{l}\text { Weight } \\
\text { losses } \\
(\%)\end{array}$ & $\begin{array}{c}\text { Damaged } \\
\text { seeds } \\
(\%)\end{array}$ & $\begin{array}{c}\text { Weight } \\
\text { losses } \\
(\%)\end{array}$ & $\begin{array}{c}\text { Damaged } \\
\text { seeds } \\
(\%)\end{array}$ & $\begin{array}{c}\text { Weight } \\
\text { losses } \\
(\%)\end{array}$ & $\begin{array}{c}\text { Damaged } \\
\text { seeds } \\
(\%)\end{array}$ & $\begin{array}{l}\text { Weight } \\
\text { losses } \\
(\%)\end{array}$ & $\begin{array}{c}\text { Damaged } \\
\text { seeds } \\
(\%)\end{array}$ & $\begin{array}{l}\text { Weight } \\
\text { losses } \\
(\%)\end{array}$ \\
\hline \multirow{3}{*}{ Nogos } & 0.125 & $0.33 \mathrm{e}$ & $0.13 \mathrm{~d}$ & $0.66 \mathrm{~d}$ & $0.20 \mathrm{f}$ & $0.33 \mathrm{~d}$ & $0.66 \mathrm{e}$ & $0.0 \mathrm{~b}$ & $0.0 \mathrm{~b}$ & $0.0 \mathrm{~b}$ & 0 \\
\hline & 0.0625 & $0.66 \mathrm{e}$ & $0.26 \mathrm{~d}$ & $1.0 \mathrm{~d}$ & 0.46 ef & $0.33 \mathrm{~d}$ & $0.13 \mathrm{e}$ & $0.33 \mathrm{~b}$ & $0.60 \mathrm{~b}$ & $0.0 \mathrm{~b}$ & 0 \\
\hline & 0.0312 & $1.0 \mathrm{e}$ & $0.40 \mathrm{~d}$ & $1.33 \mathrm{~d}$ & 0.86 def & $0.66 \mathrm{~d}$ & 0.46 cde & $0.33 \mathrm{~b}$ & $0.13 b$ & $0.66 \mathrm{~b}$ & 0 \\
\hline \multirow{3}{*}{ Malathion } & 0.125 & $0.33 \mathrm{e}$ & $0.06 \mathrm{~d}$ & $1.0 \mathrm{~d}$ & $0.20 \mathrm{f}$ & $1.66 \mathrm{bcd}$ & $0.26 \mathrm{de}$ & $0.33 \mathrm{~b}$ & $0.0 \mathrm{~b}$ & $0.0 \mathrm{~b}$ & 0 \\
\hline & 0.0625 & $0.66 \mathrm{e}$ & $0.20 d$ & $2.0 \mathrm{~cd}$ & 0.46 ef & $2.0 \mathrm{bcd}$ & 0.46 cde & $0.33 \mathrm{~b}$ & $0.06 \mathrm{~b}$ & $0.33 \mathrm{~b}$ & 0 \\
\hline & 0.0312 & $2.0 \mathrm{de}$ & $0.73 \mathrm{~cd}$ & $2.0 \mathrm{~cd}$ & 0.46 ef & $2.66 \mathrm{bcd}$ & 0.80 cde & $1.0 \mathrm{~b}$ & $0.20 \mathrm{~b}$ & $0.33 \mathrm{~b}$ & 0 \\
\hline \multirow{3}{*}{ Limper } & 0.125 & $14.67 \mathrm{~b}$ & $1.33 \mathrm{bc}$ & $1.66 \mathrm{~cd}$ & $1.20 \mathrm{cde}$ & $2.33 b c d$ & $1.00 \mathrm{bcd}$ & $0.0 \mathrm{~b}$ & $0.0 \mathrm{~b}$ & $0.0 \mathrm{~b}$ & 0 \\
\hline & 0.0625 & $16.67 b$ & $1.86 \mathrm{~b}$ & $3.66 \mathrm{bc}$ & $1.60 \mathrm{bcd}$ & 3.0 bc & $1.06 \mathrm{bc}$ & $0.33 \mathrm{~b}$ & $0.06 \mathrm{~b}$ & $0.33 \mathrm{~b}$ & 0 \\
\hline & 0.0312 & $17.67 \mathrm{~b}$ & $1.86 \mathrm{~b}$ & $4.66 \mathrm{~b}$ & $1.93 \mathrm{bc}$ & $3.33 \mathrm{~b}$ & $1.53 \mathrm{~b}$ & $1.33 \mathrm{~b}$ & $0.20 \mathrm{~b}$ & $0.66 \mathrm{~b}$ & 0 \\
\hline \multirow{3}{*}{ Sevin } & 0.125 & $3.33 \mathrm{de}$ & $0.40 \mathrm{~d}$ & $1.66 \mathrm{~cd}$ & 1.06 def & $2.0 \mathrm{bcd}$ & 0.53 cde & $0.0 \mathrm{~b}$ & $0.0 \mathrm{~b}$ & $0.0 \mathrm{~b}$ & 0 \\
\hline & 0.0625 & $4.66 \mathrm{~d}$ & $0.80 \mathrm{~cd}$ & $1.66 \mathrm{~cd}$ & $1.93 \mathrm{bc}$ & $3.0 \mathrm{bc}$ & 0.66 cde & $0.33 \mathrm{~b}$ & $0.06 \mathrm{~b}$ & $0.0 \mathrm{~b}$ & 0 \\
\hline & 0.0312 & $10.67 \mathrm{c}$ & $1.46 \mathrm{bc}$ & $2.0 \mathrm{~cd}$ & $2.13 b$ & $3.66 \mathrm{~b}$ & $1.00 \mathrm{bcd}$ & $1.0 \mathrm{~b}$ & $0.13 b$ & $0.66 \mathrm{~b}$ & 0 \\
\hline Control & & $37.33 \mathrm{a}$ & $13.80 \mathrm{a}$ & $21.0 \mathrm{a}$ & $15.66 \mathrm{a}$ & $22.67 \mathrm{a}$ & $12.00 \mathrm{a}$ & $5.66 \mathrm{a}$ & $4.00 \mathrm{a}$ & $6.0 \mathrm{a}$ & 4.06 \\
\hline
\end{tabular}

Note: Percentage having same letter(s) did not differ significantly.

\section{Effect of Insecticides on Seed Germination}

Seeds of lentil, gram, grasspea, greengram and blackgram treated with $0.125,0.0625$ and $0.0312 \%$ of Nogos, Malathion, Sevin and Limper including control germinated by $84.0-97.33 \%$ (Table 3). There were no significant differences of seed germination among the treatments in all five kinds of pulses. The plants after germination of seed were healthy and normal.

Table 3. Germination of insecticides treated and untreated seeds of five different pulses

\begin{tabular}{|c|c|c|c|c|c|c|}
\hline \multirow{2}{*}{ Insecticides } & \multirow{2}{*}{$\begin{array}{l}\text { Dose } \\
(\% \mathrm{Al})\end{array}$} & \multicolumn{5}{|c|}{ Germinated seeds (\%) } \\
\hline & & Lentil & Gram & Grasspea & Greengram & Blackgram \\
\hline \multirow{3}{*}{ Nogos } & 0.125 & 96.7 & 97.3 & 88.0 & 90.7 & 92.0 \\
\hline & 0.0625 & 88.0 & 96.0 & 86.7 & 92.0 & 85.3 \\
\hline & 0.0312 & 84.0 & 96.0 & 86.7 & 85.3 & 89.3 \\
\hline \multirow{3}{*}{ Malathion } & 0.125 & 85.3 & 88.0 & 85.3 & 92.0 & 89.3 \\
\hline & 0.0625 & 84.0 & 89.3 & 86.7 & 86.7 & 90.7 \\
\hline & 0.0312 & 88.0 & 90.7 & 85.3 & 89.3 & 88.0 \\
\hline \multirow{3}{*}{ Limper } & 0.125 & 86.7 & 88.0 & 85.3 & 90.7 & 89.3 \\
\hline & 0.0625 & 88.0 & 86.7 & 86.7 & 86.7 & 90.7 \\
\hline & 0.0312 & 86.0 & 84.0 & 86.7 & 90.7 & 85.3 \\
\hline \multirow[b]{2}{*}{ Sevin } & 0.125 & 80.0 & 92.0 & 89.3 & 90.7 & 92.0 \\
\hline & 0.0625 & 86.7 & 90.7 & 84.0 & 85.3 & 88.0 \\
\hline Control & 0.0312 & 85.3 & 92.0 & 85.3 & 86.7 & 89.3 \\
\hline
\end{tabular}




\section{DISCUSSION}

The adult emergence of Callosobruchus chinensis commenced 17-18 days after insecticidal treatments on the eggs. The adults were also found to emerge at the same time in untreated seeds. The adult emergence continued for a short time in the treated seeds compared to untreated condition of the pulse seeds. There were significant differences in the number of emergent adults among the treatments. The insecticides on egg bearing pulse seeds effectively controlled adult emergence by affecting egg hatching and immature development. The reduction of emergence of adults by insecticidal treatments had a similar trend in lentil, gram and grasspea seeds. The adults of $C$. chinensis emerged at a lowest proportion from the greengram and blackgram seeds compared to other three types of pulse seeds in which case the rate of emergence and the proportion of emergent dead adults followed the same rate as on other types of pulse seeds. These two types of pulse seeds being smooth and waxy surface in comparison with gram and other types of pulse seeds showed the lower number of eggs and consequently the lowest adult emergence.

The results of Nogos, Malathion, Sevin and Limper as ovicidal agent revealed that Nogos was the most effective insecticide followed by Malathion against $C$. chinensis. At higher dose of $0.125 \%$ Nogos and Malathion had sometime no beetle emergence and at lower doses of 0.0625 and $0.0312 \%$ active ingredient number of emergent beetles were appreciably small indicating that the eggs exposed to the higher dose of these insecticide could not hatch and later on failed to develop into larvae and adults. The organophosphorus insecticides were highly persistent providing complete control of $C$. chinensis 113 days after treatments and causing $90 \%$ mortality of $C$. chinensis (Ayad and Alyousef, 1988). Bang (1961) reported five complete mortality of the beetles as well as adult emergence at $4 \mathrm{ppm}$ of Malathion 57EC. The organophosphorus compounds Nogos, Malathion and Sumithion were more effective than the synthetic Pyrethroid or the Carbamate Sevin (Carbaryl) in direct and indirect (residual effect) toxicity tests on stored pulse seeds against bruchid, C. chinensis (Mohammad and Jabery, 1988).

The quantitative losses resulted in different pulse seeds by the attack of $C$. chinensis varied among the treatments. The seed damage and weight losses due to this beetle were significantly reduced in insecticidal treatments. Nogos and Malathion decreased the seed damage and weight losses significantly more than Sevin and Limper but Sevin decreased seed damage and weight losses more than Limper. The mean number of damaged seeds obtained in untreated pulse seeds was significantly higher by 57.63-94.00, 35.35-98.79, 71.11-97.39, 76.50-100 and 78.0-100\% on lentil, gram, grasspea, greengram and blackgram respectively than all other treatments. The weight losses due to damage by the pulse beetle, $C$. chinensis observed in untreated pulse seeds was signifgicantly higher than treated seeds. Insecticidal treatments reduced 80.0-96.5, 51.1-98.4, 49.0$95.66,40-100$ and cent per cent weight losses of lentil, gram, grasspea, greengram and blackgram seeds respectively. For long safe storage of pulse seeds, Malathion and Methoxyclor at concentrations above 24 ppm should be used against $C$. chinensis (Dhari et al., 1977). Fenvalerate $0.2 \%$ was the most effective compound followed by Fenitrothion $0.1 \%$ against $C$. chinensis on pulse seeds over a period of 12 months (Borika and Pawar, 1995).

The present study revealed that the insecticides did not affect the viability and germination of pulse seeds. None of the insecticidal treatments with Deltamethrin (125 ppm), Fenvalerate $(75 \mathrm{ppm})$ and Cypermethrin had an adverse effect on germination of pulse seeds (Patil et al., 1994).

\section{CONCLUSION}

Of five different pulses gram, lentil and grasspea seeds suffered from greater damage than greengram and blackgram seeds by Callosobruchus chinensis. Nogos and Malathion treatments after oviposition of the beetles inhibited more the development of immatures showing less emergence of the adults than Limper and Sevin. The organphosphorus insecticides appeared to be more toxic to eggs of $C$. chinensis than pyrethroid and carbamate. The seed damage and weight losses from one-fourth to cent per cent might be reduced by the insecticide treatments in pulse seeds infested by $C$. chinensis. The germination of the seeds was not significantly affected by the treatment of the insecticides. 


\section{LITERATURE CITED}

Akhtari, N., Sardar, M. A., Rahman, M. H., Abedin, S. M. Z. and Rahman, A. K. M. M. 1993. Feeding and oviposition preference of pulse beetle, C. chinensis on different genotypes of bean and its control. Ann Bangladesh Agric 3(2), 63-69.

Anonymous. 1978. Post-harvest losses in developing countries. National Academy of Sciences. Washington, D.C. p. 22.

Ayad, F. A. and Alyousef, E. F. 1988. Biological persistence of some insecticides and their influence on germination rate and early seedling growth of the chickpea, Cicer arietanium. Bull Entom Soc Egypt 15, 95-103.

Bang, Y. H. 1961. Laboratory Evaluation of Several Chemical protectants Against the Southern Cowpea weevil, Callosobruchus chinensis L. on stored dried bean in Korea. J Econ Entom 56(5), 588-591.

Borika, P. S. and Pawar, V. M. 1995. Relative efficacy of some grain protectants against C. chinensis (L.). Pesticide Res J India 7(2), 125-127.

Dhari, K., Dass, N. and Daas, R. 1977. Persistent toxicity of some insecticides to adult of pulse beetle, Callosobruchus chinensis Linn. J Entom Univ Agric Tech India 39(4), 361364.

Mohammad, A. K. H. and Al-Jabery, I. A. R. 1988. Comparative toxicity of some insecticides in the laboratory to the Southern Cowpea weevil, C. chinensis (L.) and the parasite, Anisopteromalus calandrae (How). Mesopotamia J Agric Iraq 20(1), 289-306.

Patil, R. K., Nawale, R. N. and Mote, U. N. 1964. Efficacy of synthetic pyrethroids as seed protectants of pigeon pea against pulse beetle, C. maculatus Fab. Indian J Entom 56(1), 51-57.

Sarwar. D. M., Quader, M. and Wahab, M. A. 1981. Status of research on lentil (Lens culinaris Medik) at BARI. In "Proceedings of the National Workshop on Pulses" (A. K. Kaul, Ed.), August 1981. pp. 3-8.

Sharma, S. S. 1984. Review of literature of the losses caused by Callosobruchus species (Bruchidae : Coleoptera) during storage of pulses. Bull Grain Tech 22(1), 62-68. 